\title{
Bacterial DNA is a prognostic factor for mortality in patients who recover from spontaneous bacterial peritonitis
}

\author{
Iliana Mania, Georgia Vrioni ${ }^{b}$, Emilia Hadziyannis ${ }^{a}$, Theodoros Alexopoulos ${ }^{a}$, Larisa Vasilievaa, \\ Athanasia Tsiriga ${ }^{a}$, Constantinos Tsiamis ${ }^{b}$, Athanasios Tsakris ${ }^{b}$, Spyros P. Dourakis ${ }^{a}$, \\ Alexandra Alexopoulou ${ }^{a}$
}

Medical School, National and Kapodistrian University of Athens, Hippokration Hospital; Medical School, National and Kapodistrian University of Athens, Athens, Greece

\section{Abstract}

Background Spontaneous bacterial peritonitis (SBP) is associated with a high mortality. The aim
was to investigate whether bacterial deoxyribonucleic acid (bactDNA) could offer an accurate
identification of pathogens and to explore its prognostic role during and early after an SBP episode.

Methods Consecutive patients with SBP (SBP-group) and patients with decompensated cirrhosis without SBP/bacterascites (control-group) were enrolled. Standard culture methodology was used to isolate and identify pathogens from blood and ascitic fluid (AF). The SeptiFast test was used to identify bactDNA directly from $\mathrm{AF}$.

Results Fifty-five patients, median age 60 (interquartile range [IQR] 53-74), model-for-end-stage liver disease (MELD) score 18 (IQR 13-29), with SBP were prospectively included. AF cultures were positive in 52.7\% (17.2\% drug-resistant bacteria) and bactDNA in $29.1 \%$ (58.2\% combined sensitivity). BactDNA results were $84.6 \%$ concordant with AF cultures. Three patients had positive bactDNA in the culture-negative SBP-group. BactDNA was negative in all 36 of the control group (100\% specificity). In multivariate analysis for 7-day survival, factors adversely affecting outcome were MELD $(\mathrm{P}=0.049)$ and $\mathrm{C}$-reactive protein $(\mathrm{P}=0.012)$. After patients who died during the first week post-admission were excluded, patients with positive bactDNA had a poor prognosis compared to those with a negative test $(\log$-rank $\mathrm{P}=0.005)$. Variables independently associated with 30-day mortality were neutrophil-to-lymphocyte ratio $(\mathrm{P}=0.011)$ and positive bactDNA $(\mathrm{P}=0.020)$.

Conclusions No evidence was found for the usefulness of bactDNA to improve bacterial identification during an SBP episode. However, bactDNA was a predictor of 30-day mortality in the subset of patients who recovered from the infection episode.

Keywords Spontaneous bacterial peritonitis, culture-positive SBP, neutrophil-to-lymphocyte ratio, bacterial DNA, survival

Ann Gastroenterol 2021; 34 (x): 1-10 a2 ${ }^{\text {nd }}$ Department of Internal Medicine and Research Laboratory, Medical School, National and Kapodistrian University of Athens, Hippokration Hospital, Athens, Greece (Iliana Mani, Emilia Hadziyannis, Theodoros Alexopoulos, Larisa Vasilieva, Athanasia Tsiriga, Spyros P. Dourakis, Alexandra Alexopoulou); ${ }^{\mathrm{b}}$ Department of Microbiology, Medical School, National and Kapodistrian University of Athens, Athens, Greece (Georgia Vrioni, Constantinos Tsiamis, Athanasios Tsakris)

\section{Conflict of Interest: None}

Correspondence to: Iliana Mani, $2^{\text {nd }}$ Department of Medicine and Research Laboratory, Medical School, National and Kapodistrian University of Athens, Hippokration Hospital, 114 Vas Sophias St., Athens, Greece, e-mail: ilianamani@windowslive.com

Received 4 April 2021; accepted 26 May 2021; published online 14 September 2021

DOI: https://doi.org/10.20524/aog.2021.0665

\section{Introduction}

Spontaneous bacterial peritonitis (SBP) is defined by the presence of $>250 \times 10^{9}$ neutrophils/L in ascitic fluid (AF) of patients with cirrhosis in the absence of an intra-abdominal source of infection or malignancy [1]. It is associated with a high mortality during first hospitalization, ranging from 15$20 \%[2,3]$, while one-year mortality after the first episode is $66 \%[4]$.

Colorimetric (BacTec) systems and bedside inoculation of ascites into blood culture bottles have improved the sensitivity of classical culture techniques but failed to identify the causative bacteria in more than $23 \%$ of neutrocytic ascites cases [5]. However, prompt initiation of accurate empirical antibiotic therapy is essential in the management of patients 
with SBP, as delays and/or inappropriate therapy are associated with a greater mortality [6,7]. The choice of initial empirical antibiotic treatment should be based on local epidemiological data related to antibiotic resistance and origin of infection: community-acquired (CA), nosocomial or health-careassociated (HCA) [8].

Detection of fragments of bacterial deoxyribonucleic acid (bactDNA) in patients with SBP is a very promising technique. The use of a multiplex polymerase chain reaction (PCR) method in peritoneal fluid may constitute a sensitive and prompt means for bactDNA identification. This method has already been used in cases of sepsis in order to effectively choose a more accurately targeted antibiotic treatment [9-11]. BactDNA is not only detected in SBP cases, but is also a surrogate bacterial translocation biomarker. Its presence in peritoneal fluid is associated with pathological bacterial translocation and marked systemic inflammatory response [12]. Many investigators found that bactDNA was a marker of poor outcomes in patients without infection. More specifically, it was demonstrated that the presence of bactDNA in serum and ascites of cirrhotic patients without overt infection was a poor prognostic factor and was related to the development of acute-on-chronic liver failure (ACLF) [13]. Other researchers showed that non-infected but positive bactDNA patients had a higher relative risk for death, hepatorenal syndrome, and SBP [14]. It was also demonstrated that patients' survival was positively associated with AF bactDNA levels determined by a culture-independent 16S rRNA gene-based method [15]. On the other hand, bactDNA in patients without overt or suspected infection was not proved to be a predictor of survival $[16,17]$. However, the prognostic role of bactDNA in patients who just recovered from an SBP episode has not been investigated so far.

The aim of the present study was to explore whether bactDNA assessed by a commercially available broad-range multiplex PCR procedure in AF [18] could provide early and accurate identification of pathogens in SBP, and to investigate the prognostic role of bactDNA in relation to outcomes during and after an episode of SBP.

\section{Patients and methods}

\section{Study population}

This observational study was conducted in a single tertiary center from September 2017 to May 2020. SBP was diagnosed according to international guidelines [19]. Data were prospectively collected from 55 consecutive patients with decompensated cirrhosis and SBP. Patients with extrahepatic solid or hematological malignancy, human immunodeficiency virus infection, previous transplantation or any other type of immunodeficiency, multi-microbial infections, secondary bacterial peritonitis were excluded, as were those on peritoneal dialysis.

Thirty-six patients with decompensated cirrhosis admitted for a scheduled large-volume paracentesis were used as control group to assess the sensitivity and specificity of the bactDNA method to identify causative bacteria. Five (13.9\%) controls had a history of SBP. The median time interval between the previous SBP episode and the current data collection was 8 (range 1-11) months. The study protocol was approved by the hospital's Ethics Committee. All study participants or their relatives provided informed written consent prior to study enrolment.

\section{Treatment strategy}

Diagnostic paracentesis of ascites was performed on admission, at $48 \mathrm{~h}$ post admission to evaluate the result of empirical antibiotic treatment, and after clinical resolution of the SBP episode. Soon after the SBP diagnosis, empirical treatment was administered intravenously and was maintained or modified if the treatment was not appropriate (according to the in vitro antibiotic susceptibility test), or if the AF neutrophil count reduction calculated at $48 \mathrm{~h}$ post initiation of empirical treatment did not reach $25 \%$. Infections were classified as HCA in patients with a hospitalization for at least 2 days in the previous 6 months, nosocomial when developed more than $48 \mathrm{~h}$ after admission, and CA when they were present on admission or developed within the first $48 \mathrm{~h}$ after admission in the absence of previous hospitalization in the previous 6 months [20]. An empirical selection of antibiotics was made according to current guidelines [19] and local epidemiological data for bacterial resistance $[21,22]$. SBP was considered cured if neutrophil count was $<250 \times 10^{9} / \mathrm{L}$ after 5 days of appropriate antibiotic treatment. All patients were followed for 30 days, empirical treatment was recorded, and mortality was evaluated at 7 and 30 days.

\section{Data collection}

Clinical and laboratory data (in both blood and AF) were obtained on admission (at baseline) and in those who recovered at day 8 post-admission. Severity of liver disease was assessed by the model for end-stage liver disease (MELD) and Child-Pugh scores. ACLF was diagnosed in patients who fulfilled the established criteria of the CANONIC study [23]. AF white cell, neutrophil and lymphocyte counts were assessed by light microscopy.

\section{Bacterial cultures and definition of multi-drug-resistant bacteria}

Blood and ascitic samples were collected on admission, before initiation of any therapeutic intervention. Specifically, diagnostic paracentesis and inoculation of AF into blood culture bottles for aerobic and anaerobic bacteria was routinely performed at bedside and simultaneous blood cultures were performed. Skin disinfection for both procedures was performed using $70 \%$ isopropyl alcohol followed by $2 \%$ 
chlorhexidine. Both disinfectants were allowed to dry for at least $30 \mathrm{sec}$. The rubber covers of the culture bottles were also disinfected with $70 \%$ isopropyl alcohol prior to blood inoculation. Sterile gloves were used for both venipuncture and paracentesis of ascites. Finally, to further decrease the risk of contamination, the 2-needle technique was applied, according to which the needle used for the initial sample collection was replaced by a new one prior to sample inoculation in the culture bottles.

Aerobic, anaerobic and broth cultures were initiated in BACTEC FX (Becton, Dickinson) blood culture bottles. All the isolated organisms were identified by the VITEK2 system (BioMérieux, Marcy l'Étoile, France). Antibiotic susceptibility testing was performed by the Kirby-Bauer method according to Clinical and Laboratory Standards Institute guidelines [24]. The minimum inhibitory concentrations were determined by Vitek2 Compact (BioMérieux, Marcy l'Étoile, France) and MIC Test Strips (Liofilchem, Roseto Degli Abruzzi, Italy). The drug-resistant bacteria were defined according to current guidelines [25].

\section{BactDNA detection}

First, extra AF samples were collected at enrolment in a sterile tube, stored in aliquots at $-80^{\circ} \mathrm{C}$ and thawed once before the experiment. The multiplex PCR applied at the study was SeptiFast test (Roche Diagnostics, Mannheim, Germany), designed to identify gram-positive microorganisms (Staphylococcus aureus, coagulase-negative Staphylococcus, Streptococcus pneumoniae, Streptococcus spp, Enterococcus faecium, Enterococcus faecalis), gram-negative microorganisms (Escherichia coli, Klebsiella pneumoniae/oxytoca, Serratia marescens, Enterococcus cloacae/aerogenes, Proteus mirabilis, Acinetobacter baumanii, Pseudomonas aeruginosa, Stenotrophomonas maltophilia), and fungi (Candida albicans, C. tropicalis, C. parapsilosis, C. glabrata, C. krusei, and Aspergillus fumigates). The sensitivity of the method was demonstrated to be 30 colony-forming units (CFU) per $\mathrm{mL}$ for all the aforementioned pathogens, except coagulase-negative Staphylococcus, Streptococcus spp and C. glabrata, for which the detection limit was $100 \mathrm{CFU} / \mathrm{mL}$ [26]. The main advantages of the method were the identification of a wide panel of microorganisms (up to 25 pathogens commonly involved in systemic infections), the short time needed to yield results, ranging from 5-6 h, and the minimal need for manual sample handling [27].

According to our methodology, $1.5 \mathrm{~mL}$ of ascites was analyzed for every patient. DNA extraction was performed using the SeptiFast Lys and Prep Kit M Grade (Roche Diagnostics, Basel, Switzerland) and DNA amplification with the Light-Cycler ${ }^{\varpi} 2.0$ system (Roche Diagnostics, Basel, Switzerland). The 2 procedures were conducted independently to minimize the risk of contamination. After amplification, positive samples were identified by dye-labeled hybridization probes measured by fluorescence. Results were considered to be valid only when the negative control turned out to be negative. Finally, the software is equipped with an extra intrinsic safety valve to reduce rates of false-positive results for coagulase-negative Staphylococcus and Streptococcus spp, namely a crossing-point cutoff rule, according to which these pathogens are thought to arise from contamination when the crossing-point value is less than 20. The amplified amplicons were characterized by Septi-Fast Identification Software (Roche diagnostics, $\mathrm{GmbH}$ ), using the melting profile of amplified products. The melting point software allowed the identification of the pathogens at the genus or species level. Only AF samples were examined. BactDNA was assessed once at initiation of infection in SBP patients and on admission in control group.

\section{Statistical analysis}

Quantitative and qualitative variables were expressed as median (interquartile range [IQR]) and number of cases (percentage), respectively. Comparisons were conducted using the Mann-Whitney $U$ test for continuous and the chi-square test for categorical variables. Survival was estimated firstly at 7 days and then at 30 days (after excluding patients who died during the SBP episode). To identify independent prognostic factors affecting survival, variables that achieved a P-value $<0.05$ in the univariate analysis were included in the multivariate model, based on a proportional hazards Cox regression model. Hazard ratios (HR) and 95\% confidence intervals (CI) were calculated. After excluding patients who died during the first episode of SBP (7 days), the cumulative probability of death at 30 days was estimated via the Kaplan-Meier method. All statistical analyses were performed using the statistical package SPSS (version 21; SPSS Inc., Chicago, Ill., USA).

\section{Results}

\section{Baseline characteristics}

Table 1 presents the baseline characteristics of the SBP patients. Patients with culture-positive compared to those with culture-negative SBP had more severe liver disease, according to MELD and Child-Pugh scores, presented ACLF more often and had a more vigorous inflammatory reaction, both in blood, expressed as higher neutrophil-to-white blood cell and neutrophil-to-lymphocyte ratios (NWR and NLR, respectively), and in AF, expressed as higher white-cell and neutrophil counts. Patients with culture-positive compared to those with culture-negative SBP had lower total protein and albumin in AF. In contrast, no statistically significant differences between bactDNA positive and negative baseline characteristics were observed, though there was a trend towards higher C-reactive protein (CRP) and more frequent manifestations of hepatic encephalopathy. No 
Table 1 Epidemiological, clinical and laboratory baseline characteristics of patients who recovered from spontaneous bacterial peritonitis, according to ascitic fluid culture and bacterial DNA results

\begin{tabular}{|c|c|c|c|c|c|c|c|}
\hline Characteristics & $\begin{array}{c}\text { Total } \\
(\mathrm{N}=55)\end{array}$ & $\begin{array}{c}\text { Culture-positive } \\
\text { SBP } \\
(\mathrm{N}=29)\end{array}$ & $\begin{array}{c}\text { Culture-negative } \\
\text { SBP } \\
(\mathrm{N}=26)\end{array}$ & P-value & $\begin{array}{l}\text { Bacterial DNA } \\
\text { positive } \\
(\mathrm{N}=16)\end{array}$ & $\begin{array}{c}\text { Bacterial DNA } \\
\text { negative } \\
(\mathrm{N}=39)\end{array}$ & P-value \\
\hline \multicolumn{8}{|c|}{ Median (interquartile range) or number (percentage) } \\
\hline Age & $60(53-74)$ & $60(52-75)$ & $61(55-71)$ & 0.813 & $64(53-78)$ & $60(53-69)$ & 0.197 \\
\hline $\operatorname{Sex}\left(0^{n}\right)$ & $38(69.1 \%)$ & $22(75.9 \%)$ & $16(61.5 \%)$ & 0.251 & $11(68.8 \%)$ & $27(69.2 \%)$ & 0.972 \\
\hline $\begin{array}{l}\text { Etiology of liver } \\
\text { disease } \\
\text { Alcoholic } \\
\text { Viral } \\
\text { Miscellaneous }\end{array}$ & $\begin{array}{l}29(52.7 \%) \\
11(20.0 \%) \\
15(27.3 \%)\end{array}$ & $\begin{array}{c}18(62.1 \%) \\
5(17.2 \%) \\
6(20.7 \%)\end{array}$ & $\begin{array}{c}11(42.3 \%) \\
6(23.1 \%) \\
9(34.6 \%)\end{array}$ & 0.329 & $\begin{array}{c}10(62.5 \%) \\
2(12.5 \%) \\
4(25.0 \%)\end{array}$ & $\begin{array}{c}19(48.7 \%) \\
9(23.1 \%) \\
11(28.2 \%)\end{array}$ & 0.581 \\
\hline \multicolumn{8}{|l|}{$\begin{array}{l}\text { Severity of liver } \\
\text { disease }\end{array}$} \\
\hline $\begin{array}{l}\text { Child-Pugh } \\
\text { score } \\
\text { A }\end{array}$ & $\begin{array}{c}10(9-12) \\
0\end{array}$ & $11(10-13)$ & $10(8-11)$ & 0.002 & $11(10-13)$ & $10(9-12)$ & 0.329 \\
\hline $\begin{array}{l}\text { B } \\
\text { C }\end{array}$ & $\begin{array}{l}14(25.5 \%) \\
41(74.5 \%)\end{array}$ & $\begin{array}{c}4(13.8 \%) \\
25(86.2 \%)\end{array}$ & $\begin{array}{l}10(38.5 \%) \\
16(61.5 \%)\end{array}$ & 0.036 & $\begin{array}{c}3(18.8 \%) \\
13(81.2 \%)\end{array}$ & $\begin{array}{l}11(28.2 \%) \\
28(71.8 \%)\end{array}$ & 0.465 \\
\hline $\begin{array}{l}\text { Acute-on- } \\
\text { chronic liver } \\
\text { failure } \\
\text { Encephalopathy } \\
\text { episode }\end{array}$ & $21(38.2 \%)$ & $16(55.2 \%)$ & $5(19.2 \%)$ & 0.006 & $8(50.0 \%)$ & $13(33.3 \%)$ & 0.248 \\
\hline \multicolumn{8}{|l|}{$\begin{array}{l}\text { Inflammatory } \\
\text { reaction (blood) }\end{array}$} \\
\hline $\begin{array}{l}\text { White blood } \\
\text { cell count } \\
\times 10^{9} / \mathrm{L}\end{array}$ & $7.65(5.49-10.61)$ & $7.92(6.62-11.21)$ & $6.75(5.05-10.16)$ & 0.206 & $7.27(5.38-11.39)$ & $7.66(5.71-1.49)$ & 0.897 \\
\hline $\begin{array}{l}\text { Neutrophil-to- } \\
\text { white-blood- } \\
\text { cell ratio }(\times 10)\end{array}$ & $8.0(7.5-8.6)$ & $8.2(7.8-8.9)$ & $7.7(6.9-8.5)$ & 0.013 & $8.2(7.6-8.8)$ & $7.9(7.4-8.5)$ & 0.364 \\
\hline $\begin{array}{l}\text { Neutrophil- } \\
\text { to-lymphocyte } \\
\text { ratio }\end{array}$ & $10.9(6.5-17.8)$ & $13.0(9.4-18.0)$ & $6.9(4.5-13.5)$ & 0.005 & $11.8(7.9-17.9)$ & $9.7(5.8-17.8)$ & 0.374 \\
\hline $\begin{array}{l}\text { C-reactive } \\
\text { protein }(\mathrm{mg} / \mathrm{L})\end{array}$ & $46(21-119)$ & $85(28-133)$ & $34(17-83)$ & 0.055 & $109(31-133)$ & $36(19-87)$ & 0.092 \\
\hline $\begin{array}{l}\text { Positive blood } \\
\text { culture }\end{array}$ & $7(12.7 \%)$ & $7(24.1 \%)$ & $0(0.0 \%)$ & 0.007 & $4(25.0 \%)$ & $3(7.7 \%)$ & 0.080 \\
\hline \multicolumn{8}{|l|}{$\begin{array}{l}\text { Ascitic fluid } \\
\text { characteristics }\end{array}$} \\
\hline $\begin{array}{l}\text { White cell } \\
\text { count } \times 10^{9} / \mathrm{L}\end{array}$ & $1.65(0.07-3.09)$ & $2.50(1.14-4.55)$ & $0.89(619-1.80)$ & 0.001 & $2.10(1.24-4.57)$ & $1.00(670-2.70)$ & 0.092 \\
\hline $\begin{array}{l}\text { Neutrophil } \\
\text { count } \times 10^{9} / \mathrm{L}\end{array}$ & $0.81(0.42-2.32)$ & $1.73(0.81-3.55)$ & $0.50(0.36-0.83)$ & $<0.001$ & $1.68(0.76-3.04)$ & $0.66(0.40-1.87)$ & 0.097 \\
\hline $\begin{array}{l}\text { Total protein } \\
(\mathrm{g} / \mathrm{dL})\end{array}$ & $1.3(0.9-2.1)$ & $1.2(0.9-1.6)$ & $1.9(1.2-2.6)$ & 0.005 & $1.7(1.1-2.1)$ & $1.3(0.9-2.2)$ & 0.562 \\
\hline $\begin{array}{l}\text { Albumin } \\
\text { (g/dL) }\end{array}$ & $0.8(0.5-1.1)$ & $0.6(0.4-0.9)$ & $1(0.7-1.3)$ & 0.005 & $0.8(0.4-1.1)$ & $0.7(0.5-1.1)$ & 0.758 \\
\hline \multicolumn{8}{|l|}{ Mortality } \\
\hline 7 days & $8(14.5 \%)$ & $7(24.1 \%)$ & $1(3.8 \%)$ & 0.033 & $4(25.0 \%)$ & $4(10.3 \%)$ & 0.159 \\
\hline $\begin{array}{l}\text { 8-30 days (47 } \\
\text { patients) }\end{array}$ & $14(29.8 \%)$ & $8(36.4 \%)$ & $6(24 \%)$ & 0.355 & $7(58.3 \%)$ & $7(20.0 \%)$ & 0.012 \\
\hline
\end{tabular}

$\overline{\text { SBP, spontaneous bacterial peritonitis; } M E L D \text {, model for end-stage liver disease }}$

prophylactic treatment for SBP was recorded. Resolution of the infection occurred in all SBP patients who survived the episode (less than $250 \times 10^{9} / \mathrm{L}$ neutrophil count in $\mathrm{AF}$ at paracentesis). 


\section{Microbiological and molecular studies}

AF cultures were positive in $29(52.7 \%)$ cases of SBP (Table 2, Fig. 1). Gram-positive cocci were found in 11 cases (37.9\%). The type of bacteria is illustrated in Table 2. Twentyfive patients (75.8\%) were classified as having HCA and/or nosocomial infections. According to if possible the antibiotic susceptibility test, 19 cases $(65.5 \%)$ were over-treated by empirical treatment, 7 (24.1\%) received appropriate antibiotic treatment and 3 (10.3\%) were undertreated (Table 2).

Sixteen bacteria were identified by multiplex PCR in patients with SBP (29.1\% sensitivity) and the majority (56.3\%) were gram-positive. Both methods had $58.2 \%$ combined sensitivity for bacteria identification. The concordance of bactDNA with the blood culture method was $84.6 \%$ (11/13 cases) (Fig. 1). More specifically, cultures isolated E. coli and E. faecium whereas bactDNA identified E. cloacae and Streptococcus spp, respectively. In 3 samples, cultures yielded negative results but bactDNA method identified Streptococcus spp $(\mathrm{n}=2)$ and E. cloacae $(\mathrm{n}=1)$ (Table 2). BactDNA results were negative in the entire control group, giving $100 \%$ specificity.

No therapeutic decisions were based on the bactDNA method, according to the design of the study. However, if the results of bactDNA had been known $6 \mathrm{~h}$ after the diagnostic paracentesis, treatment would have been modified in 8 of $16(50 \%)$ bactDNA positive cases (the antibiotic treatment would have been de-escalated in 6 and upgraded in 2). In 3 cases, the bactDNA method could not differentiate antibioticsensitive E. coli from E. coli extended-spectrum $\beta$-lactamasepositive (ESBL), so treatment could not have been appropriately de-escalated (Table 2).

\section{Survival analysis at 7 and 30 days}

In Cox univariate analysis, variables associated with 7-day mortality included MELD score $(\mathrm{P}=0.008)$, CRP ( $\mathrm{P}=0.008)$, NWR $(\mathrm{P}=0.018)$, NLR $(\mathrm{P}=0.001)$, neutrophil count in $\operatorname{AF}(\mathrm{P}=0.031)$, and positive blood culture $(\mathrm{P}=0.021)$. In multivariate Cox regression analysis, factors adversely affecting outcomes were MELD score (HR 1.126, 95\%CI

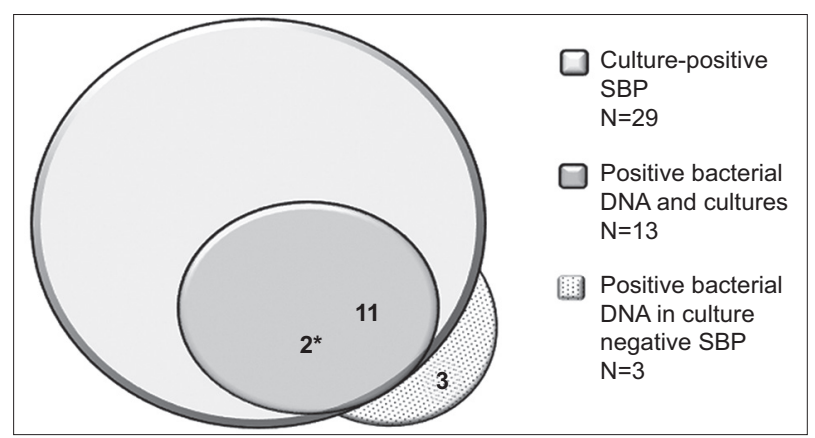

Figure 1 Sensitivity, concordance and divergence of positive cultures and presence of bacterial DNA in ascitic fluid in patients with spontaneous bacterial peritonitis (SBP)

${ }^{*}$ Discrepant results
1.001-1.268; $\mathrm{P}=0.049)$, and CRP (HR 1.023, 95\%CI 1.0051.041; $\mathrm{P}=0.012$ ) (Table 3).

After the exclusion of patients who died during the first episode of SBP ( $n=8), 7$ of 12 and 7 of 35 patients died in the bactDNApositive and bactDNA-negative subgroups, respectively, during the 30 day-period following resolution of infection (log rank $\mathrm{P}=0.005$ ) (Fig. 2). Variables associated with 30-day mortality in patients who recovered from the SBP episode, according to Cox univariate analysis, included MELD score ( $\mathrm{P}=0.017)$, NWR ( $\mathrm{P}=0.003)$, NLR $(\mathrm{P}=0.005)$, ACLF $(\mathrm{P}=0.005)$, neutrophils in AF $(\mathrm{P}=0.006)$, encephalopathy $(\mathrm{P}=0.016)$, and positive bactDNA $(\mathrm{P}=0.01)$ (Table 4$)$. In the multivariate Cox regression analysis, factors adversely affecting outcome were NLR (HR 1.117, 95\%CI 1.026-1.216; $\mathrm{P}=0.011$ ) and positive bactDNA (HR 4.142, 95\%CI 1.248-13.739; $\mathrm{P}=0.020$ ) (Model 1) (Table 4). If the parameter bactDNA plus culture positive (instead of bactDNA) was included in the multivariate analysis (Model 2), the risk of death was doubled compared to bactDNA alone (HR 8.522, 95\%CI 1.877-38.678; $\mathrm{P}=0.006)$. NLR remained an independent factor for mortality (HR 1.150, 95\%CI 1.050-1.260; $\mathrm{P}=0.003$ ).

When inflammation markers determined at day 8 post admission were compared between patients (who survived after the SBP episode) with positive and negative bactDNA, respectively, the former had higher median values of NLR or NWR $(\times 10)$ than the latter: 7.169 (IQR 4.936-11.740) vs. 4.904 (IQR 2.720-8.000), $\mathrm{P}=0.045$, or 7.515 (IQR 7.000-8.180) vs. 6.790 (IQR 6.180-7.560), $\mathrm{P}=0.035$ ], respectively (data not shown in Tables).

Recurrence of SBP was not observed during the 30 days following resolution of SBP. Causes of 30-day mortality in the 22 patients were as follows: ACLF in 13 (59.1\%), septic shock in $6(27.3 \%)$, variceal bleeding in $2(9.1 \%)$, and hepatorenal syndrome in $1(4.5 \%)$. During the acute episode, causes of death were septic shock in $4(50 \%)$ patients, liver failure in $3(37.5 \%)$, and hepatorenal syndrome in $1(12.5 \%)$.

\section{Discussion}

In the present study, we found that bactDNA was not useful for the early and accurate identification of the bacteria involved in an SBP episode. However, it was a prognostic marker of a poor outcome in the early 30 -day period after resolution of the infection episode.

First, we examined the clinical relevance of bactDNA using a commercially available multiplex PCR method in the management of patients with SBP. This particular method was designed to identify a wide range of both gram-positive and gram-negative pathogens [9-11]. The method is rapid and handoperated manipulation of samples is limited [27]. Appendort et al [18], used this method to identify bactDNA in 18 patients with and 133 without SBP, and obtained rather low sensitivity and specificity results. In our study, the bactDNA method identified fewer bacteria compared to those isolated by culture. Even though the molecular method had similar results to the conventional bacterial culture, no major discrepancies and high specificity, it was characterized by low sensitivity and a lack of determination 
Table 2 Isolated micro-organism, bactDNA results and evaluation of empirical treatment in SBP cases

\begin{tabular}{|c|c|c|c|c|c|c|}
\hline $\begin{array}{l}\text { Microorganism } \\
\text { isolated by ascitic } \\
\text { fluid culture }\end{array}$ & $\begin{array}{l}\text { Microorganism } \\
\text { identified by } \\
\text { bactDNA }\end{array}$ & $\begin{array}{l}\text { Healthcare } \\
\text { associated / } \\
\text { nosocomial }\end{array}$ & $\begin{array}{l}\text { Empirical } \\
\text { treatment }\end{array}$ & $\begin{array}{l}\text { Appropriate/Under/ } \\
\text { Over-treatment } \\
\text { according to culture }\end{array}$ & $\begin{array}{l}\text { Potential treatment } \\
\text { modification } \\
\text { according to bactDNA }\end{array}$ & $\begin{array}{l}\text { Outcome } \\
\text { day } 7\end{array}$ \\
\hline S. aureus $M R S A^{*}$ & - & $\mathrm{Y}$ & $\begin{array}{l}\text { Meropenem/ } \\
\text { vancomycin }\end{array}$ & $\mathrm{O}$ & & Survived \\
\hline S. mitis & - & $\mathrm{Y}$ & Meropenem & $\mathrm{O}$ & & Survived \\
\hline E. coli & - & $\mathrm{Y}$ & $\begin{array}{l}\text { Piperacillin/ } \\
\text { tazobactam }\end{array}$ & $\mathrm{O}$ & & Survived \\
\hline S. ovis & Streptococcus spp & $\mathrm{Y}$ & $\begin{array}{l}\text { Meropenem/ } \\
\text { vancomycin }\end{array}$ & $\mathrm{O}$ & De-escalation & Survived \\
\hline S. paucimobilis & - & $\mathrm{N}$ & Ceftriaxone & A & & Survived \\
\hline L. monocytogenes & - & $\mathrm{N}$ & Ceftriaxone & $\mathrm{U}$ & & Survived \\
\hline P. aeruginosa* & - & $\mathrm{Y}$ & Meropenem & A & & Survived \\
\hline P. aeruginosa* & P. aeruginosa & $\mathrm{Y}$ & Meropenem & A & No modification & Survived \\
\hline S. gallolyticus & - & $\mathrm{N}$ & Ceftriaxone & A & & Survived \\
\hline E. coli & E. coli & $\mathrm{Y}$ & Meropenem & $\mathrm{O}$ & No modification & Survived \\
\hline S. mitis & - & $\mathrm{Y}$ & $\begin{array}{l}\text { Piperacillin/ } \\
\text { tazobactam }\end{array}$ & $\mathrm{O}$ & & Survived \\
\hline E. coli & - & $\mathrm{Y}$ & Meropenem & $\mathrm{O}$ & & Survived \\
\hline E. coli & - & $\mathrm{Y}$ & $\begin{array}{l}\text { Meropenem/ } \\
\text { daptomycin }\end{array}$ & $\mathrm{O}$ & & Survived \\
\hline K. pneumoniae & - & $\mathrm{Y}$ & Meropenem & A & & Survived \\
\hline E. coli & - & $\mathrm{Y}$ & $\begin{array}{l}\text { Meropenem/ } \\
\text { daptomycin }\end{array}$ & $\mathrm{O}$ & & Survived \\
\hline E. faecalis & Streptococcus spp & $\mathrm{Y}$ & Meropenem & $\mathrm{O}$ & De-escalation & Survived \\
\hline S. marcescens & S. marcescens & $\mathrm{N}$ & Ceftriaxone & A & No modification & Survived \\
\hline E. faecalis & E. faecalis & $\mathrm{N}$ & Ceftriaxone & A & No modification & Survived \\
\hline E. coli $E S B L^{*}$ & - & $\mathrm{N}$ & Ceftriaxone & $\mathrm{U}$ & & Survived \\
\hline E. coli & E. cloacae & $\mathrm{Y}$ & $\begin{array}{l}\text { Piperacillin/ } \\
\text { tazobactam }\end{array}$ & $\mathrm{O}$ & Upgrade & Survived \\
\hline K. pneumoniae & - & $\mathrm{Y}$ & Meropenem & $\mathrm{O}$ & & Died \\
\hline E. coli & E. coli & $\mathrm{Y}$ & Meropenem & $\mathrm{O}$ & No modification & Died \\
\hline E. coli & - & $\mathrm{Y}$ & Meropenem & $\mathrm{O}$ & & Died \\
\hline E. coli & E. coli & $\mathrm{Y}$ & Meropenem & $\mathrm{O}$ & No modification & Died \\
\hline E. faecium & E. faecium & $\mathrm{Y}$ & $\begin{array}{l}\text { Meropenem/ } \\
\text { vancomycin }\end{array}$ & $\mathrm{O}$ & De-escalation & Survived \\
\hline S. pseudoporcinous & Streptococcus spp & $\mathrm{Y}$ & $\begin{array}{l}\text { Meropenem/ } \\
\text { daptomycin/ }\end{array}$ & $\mathrm{O}$ & De-escalation & Died \\
\hline E. coli & E. coli & $\mathrm{Y}$ & Meropenem & $\mathrm{O}$ & No modification & Survived \\
\hline S. pneumoniae & - & $\mathrm{N}$ & $\begin{array}{l}\text { Meropenem/ } \\
\text { vancomycin }\end{array}$ & $\mathrm{O}$ & & Died \\
\hline A. baumannii ${ }^{*}$ & A. baumannii & $\mathrm{Y}$ & Meropenem & $\mathrm{U}$ & Upgrade & Died \\
\hline- & Streptococcus spp & $\mathrm{Y}$ & $\begin{array}{l}\text { Piperacillin/ } \\
\text { tazobactam }\end{array}$ & & De-escalation & Survived \\
\hline- & E. cloacae & $\mathrm{Y}$ & Meropenem & & No modification & Survived \\
\hline- & Streptococcus spp & $\mathrm{Y}$ & $\begin{array}{l}\text { Piperacillin/ } \\
\text { tazobactam }\end{array}$ & & De-escalation & Survived \\
\hline
\end{tabular}

${ }^{*}$ multi-drug-resistant pathogen

Y, Yes; N, No; A, Appropriate; O, Overtreatment; U, Under-treatment; bactDNA, bacterial DNA 
Table 3 Univariate and multivariate Cox regression analysis of factors predicting 7-day mortality in all ( $\mathrm{N}=55)$ patients with spontaneous bacterial peritonitis (all factors were assessed at diagnosis)

\begin{tabular}{|c|c|c|c|c|}
\hline \multirow[t]{2}{*}{ Factors } & \multicolumn{2}{|c|}{ Univariate analysis } & \multicolumn{2}{|c|}{ Multivariate analysis } \\
\hline & HR 95\%CI & P-value & HR 95\%CI & P-value \\
\hline Age (per 1 year) & $1.012(0.959-1.067)$ & 0.676 & & \\
\hline Male sex & $1.329(0.268-6.584)$ & 0.728 & & \\
\hline Sodium & $0.958(0.854-1.076)$ & 0.471 & & \\
\hline MELD score & $1.103(1.026-1.185)$ & 0.008 & $1.126(1.001-1.268)$ & 0.049 \\
\hline C-reactive protein & $1.017(1.005-1.030)$ & 0.008 & $1.023(1.005-1.041)$ & 0.012 \\
\hline Neutrophil-to-white-cell ratio (blood) & $4.459(1.288-15.442)$ & 0.018 & & \\
\hline Neutrophil-to- lymphocyte ratio (blood) & $1.084(1.034-1.136)$ & 0.001 & & \\
\hline Acute-on-chronic liver failure (Yes) & $160.043(0.276-92740)$ & 0.118 & & \\
\hline Ascitic fluid neutrophil count & $1.000(1.000-1.000)$ & 0.031 & & \\
\hline Encephalopathy (Yes) & $47.277(0.138-16164)$ & 0.195 & & \\
\hline Positive ascitic culture & $7.114(0.875-57.871)$ & 0.067 & & \\
\hline Positive bacterial DNA & $2.777(0.694-11.116)$ & 0.149 & & \\
\hline Under-treatment according to cultures & $1.870(0.225-15.567)$ & 0.563 & & \\
\hline Treatment failure according to no decrease of ascitic neutrophils & $1.437(0.240-8.605)$ & 0.691 & & \\
\hline Positive blood cultures & $5.459(1.291-23.075)$ & 0.021 & & \\
\hline
\end{tabular}

HR, hazard ratio; CI, confidence interval

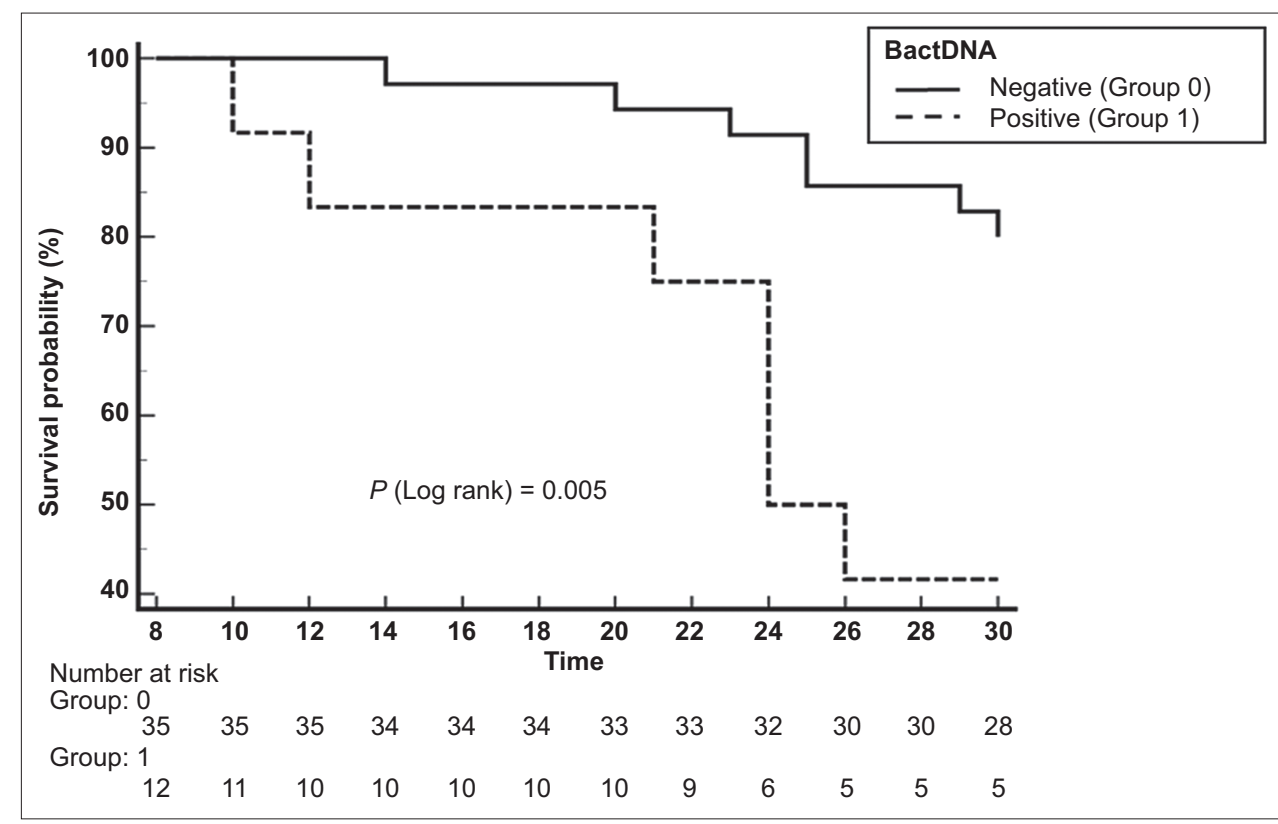

Figure 2 Kaplan-Meier curve showing 30-day survival according to baseline bacterial DNA (bactDNA) results in patients with spontaneous bacterial peritonitis who recovered from the infection

of resistant bacterial strains. Thus, the present method may not be useful for the immediate diagnosis of the causative organisms and optimization of SBP antibiotic treatment.

Even though more severe liver disease, vigorous inflammatory response and higher 7-day mortality rate were observed at baseline in patients with culture-positive compared to those with culture-negative SBP (as was also reported by previous investigators) $[28,29]$, no overt statistical difference was demonstrated between patients with positive and negative bactDNA. However, there was a trend for more frequent hepatic encephalopathy episodes and higher CRP levels in patients with positive compared to those with negative bactDNA, showing enhanced bacterial translocation and a marked inflammatory reaction in this subgroup. 
Table 4 Univariate and multivariate cox regression analysis of factors predicting 30-day mortality in patients with spontaneous bacterial peritonitis who survived the episode $(\mathrm{N}=47)$ (all factors were assessed at diagnosis)

\begin{tabular}{|c|c|c|c|c|}
\hline \multirow[t]{2}{*}{ Factors } & \multicolumn{2}{|c|}{ Univariate analysis } & \multicolumn{2}{|c|}{ Multivariate analysis } \\
\hline & HR 95\%CI & P-value & HR 95\%CI & $\mathrm{P}$-value \\
\hline Age (per 1 year) & $1.006(0.965-1.049)$ & 0.767 & & \\
\hline Male sex & $3.072(0.687-13.738)$ & 0.142 & & \\
\hline MELD score & $1.062(1.011-1.116)$ & 0.017 & & \\
\hline C-reactive protein & $1.006(0.996-1.016)$ & 0.246 & & \\
\hline Neutrophil-to-white-cell ratio (blood) & $3.211(1.478-6.973)$ & 0.003 & & \\
\hline Neutrophil-to-lymphocyte ratio (blood) & $1.096(1.029-1.168)$ & 0.005 & $\begin{array}{l}1.117(1.026-1.216) \\
1.150(1.050-1.260)\end{array}$ & $\begin{array}{l}0.011^{*} \\
0.003^{* *}\end{array}$ \\
\hline Acute-on-chronic liver failure (Yes) & $4.567(1.580-13.196)$ & 0.005 & & \\
\hline Ascitic fluid neutrophil count & $1.000(1.000-1.000)$ & 0.006 & & \\
\hline Encephalopathy (Yes) & $6.287(1.404-28.146)$ & 0.016 & & \\
\hline Positive ascitic culture & $1.636(0.567-4.718)$ & 0.362 & & \\
\hline Positive bacterial DNA & $4.027(1.402-11.566)$ & 0.010 & $4.142(1.248-13.739)$ & $0.020^{*}$ \\
\hline Positive bacterial DNA and AF culture & $7.334(2.506-21.464)$ & $<0.001$ & $8.522(1.877-38.678)$ & $0.006^{* *}$ \\
\hline Under-treatment according to cultures $(3 / 29)$ & $1.186(0.146-9.662)$ & 0.873 & & \\
\hline Treatment failure according to no decrease of ascitic neutrophil count & $1.095(0.367-3.271)$ & 0.870 & & \\
\hline Positive blood cultures & $1.165(0.152-8.908)$ & 0.883 & & \\
\hline
\end{tabular}

Researchers have studied bactDNA as a marker of both infection and bacterial translocation, and attempted to investigate its association with survival in patients with infections or suspected infections. Bruns et al, who detected bactDNA in $100 \%(5 / 5)$ culture-positive neutrocytic, $16.6 \%$ (1/6) culture-negative neutrocytic and $14.3 \%$ (8/56) culturenegative non-neutrocytic ascites samples, found that 3-month mortality did not differ amongst bactDNA groups. However, patients older than 65 years, with severe liver disease and positive bactDNA, had shorter survival [16]. Similarly, in a more recent study by the same group, bactDNA was detected by multiplex PCR in the serum and/or AF of $61 \%$ of patients with suspected infection at baseline. BactDNA was associated with SBP and bacteremia, ACLF development, encephalopathy and markers of inflammation, but was not a predictor of survival [17].

In the present study, no correlation of bactDNA with mortality was observed during the SBP episode. Other factors, such as severity of liver disease and acute inflammatory reaction (high CRP), were associated with a poor prognosis early during the SBP episode.

However, we observed that patients who recovered from the SBP episode, but had positive bactDNA at baseline, continued to die during the first month after SBP resolution from complications of cirrhosis other than SBP. More specifically, 58.3\% in the bactDNA positive subgroup died, compared with $20 \%$ in the bactDNA negative subgroup. In the univariate analysis for mortality, we found a correlation of bactDNA presence at baseline with worse outcome in patients who survived the infection episode. In multivariate analysis, bactDNA detection at inclusion was still a factor for mortality, after adjustment for multiple co-variables including age, sex, MELD, and hepatic encephalopathy. Apart from the presence of bactDNA, NLR at SBP diagnosis emerged as a predictor of mortality during the early period following resolution of the SBP episode. When we reassessed indirect inflammation parameters after resolution of the documented infection, we found that the bactDNA positive subgroup continued to have higher NLR and NWR compared to bactDNA negative patients, indicating a persisting high inflammatory response.

Moreover, the group of patients who recovered from the SBP episode, but had both positive bactDNA and AF cultures at baseline, had an even higher risk of death (double) compared to those with positive bactDNA alone. This finding was still evident even in the multivariate analysis, where the presence of positive bactDNA and AF cultures (as a sole factor) and NLR proved to be predictors of mortality after adjustment for multiple covariates. It is possible that the coexistence of both factors was associated with a more pathological bacterial translocation and a potent inflammatory response, which persisted even after the resolution of infection.

The above findings illustrated that bactDNA presence in ascites was correlated with an exaggerated inflammatory state that persisted even after resolution of infection. We may assume that the intermittent appearance of bacterial fragments in AF would explain the worse outcome of bactDNA positive patients. It was previously demonstrated that bactDNA 
fragments may persist in blood for a period of 24-72 $\mathrm{h}$ in some patients with non-neutrocytic ascites, a phenomenon related to the presence of recurrent bacterial translocation episodes [30].

A limitation of the present work is the relatively small number of patients with SBP. Nonetheless, to our knowledge, it is the largest study to assess multiplex PCR in SBP patients [1618]. Moreover, it is the first to show that bactDNA detection at diagnosis of an SBP episode is associated with early mortality after resolution of the infection.

In conclusion, the study provided no evidence to support the implementation of bactDNA detected by a standardized multiplex PCR procedure to improve immediate bacterial identification and early optimization of antibiotic treatment in patients with SBP. However, bactDNA was an independent prognostic factor of early mortality in the subset of patients who recovered from the infection.

\section{Summary Box}

\section{What is already known:}

- Prognosis of spontaneous bacterial peritonitis (SBP) remains poor, despite proper management

- Delayed or inappropriate empirical antibiotic therapy has been demonstrated to further increase mortality rates

- Sensitivity of ascitic cultures is moderate to low, even when performed according to guidelines

\section{What the new findings are:}

- Ascitic fluid (AF) bacterial DNA detected by a multiplex PCR method could not increase the sensitivity of identification and optimize the choice of antibiotic treatment in SBP

- During the SBP episode, severe liver disease and a vigorous inflammatory reaction were predictors of 7-day mortality

- Presence of AF bacterial DNA and a high neutrophil-to-lymphocyte ratio at baseline were associated with short-term mortality after resolution of the SBP episode

\section{Acknowledment}

The present study was supported by the Hellenic Association for the Study of the Liver.

\section{References}

1. Aithal GP, Palaniyappan N, China L, et al. Guidelines on the management of ascites in cirrhosis. Gut 2021;70:9-29.
2. Piano S, Fasolato S, Salinas $\mathrm{F}$, et al. The empirical antibiotic treatment of nosocomial spontaneous bacterial peritonitis: results of a randomized, controlled clinical trial. Hepatology 2016;63:12991309.

3. Fernández J, Acevedo J, Castro M, et al. Prevalence and risk factors of infections by multiresistant bacteria in cirrhosis: a prospective study. Hepatology 2012;55:1551-1561.

4. Arvaniti V, D'Amico G, Fede G, et al. Infections in patients with cirrhosis increase mortality four-fold and should be used in determining prognosis. Gastroenterology 2010;139:1246-1256, 1256.e1-e5.

5. Castellote J, Xiol X, Verdaguer R, et al. Comparison of two ascitic fluid culture methods in cirrhotic patients with spontaneous bacterial peritonitis. Am J Gastroenterol 1990;85:1605-1608.

6. Arabi YM, Dara SI, Memish Z, et al. Antimicrobial therapeutic determinants of outcomes from septic shock among patients with cirrhosis. Hepatology 2012;56:2305-2315.

7. Ginès $\mathrm{P}$, Angeli $\mathrm{P}$, Lenz K, et al; European Association for the Study of the Liver. EASL clinical practice guidelines on the management of ascites, spontaneous bacterial peritonitis, and hepatorenal syndrome in cirrhosis. J Hepatol 2010;53:397-417.

8. Jalan R, Fernandez J, Wiest R, et al. Bacterial infections in cirrhosis: a position statement based on the EASL Special Conference 2013. J Hepatol 2014;60:1310-1324.

9. Lucignano B, Ranno S, Liesenfeld O, et al. Multiplex PCR allows rapid and accurate diagnosis of bloodstream infections in newborns and children with suspected sepsis. J Clin Microbiol 2011;49:2252-2258.

10. Regueiro BJ, Varela-Ledo E, Martinez-Lamas L, et al. Automated extraction improves multiplex molecular detection of infection in septic patients. PLoS One 2010;5:e13387.

11. Lodes U, Bohmeier B, Lippert H, König B, Meyer F. PCR-based rapid sepsis diagnosis effectively guides clinical treatment in patients with new onset of SIRS. Langenbecks Arch Surg 2012;397:447-455.

12. Bellot P, García-Pagán JC, Francés R, et al. Bacterial DNA translocation is associated with systemic circulatory abnormalities and intrahepatic endothelial dysfunction in patients with cirrhosis. Hepatology 2010;52:2044-2052.

13. Zapater P, Francés R, González-Navajas JM, et al. Serum and ascitic fluid bacterial DNA: a new independent prognostic factor in noninfected patients with cirrhosis. Hepatology 2008;48:19241931.

14. El-Naggar MM, Khalil EA, El-Daker MAM, Salama MF. Bacterial DNA and its consequences in patients with cirrhosis and culturenegative, non-neutrocytic ascites. J Med Microbiol 2008;57:15331538.

15. Engelmann C, Krohn S, Prywerek D, et al. Detection of molecular bacterascites in decompensated cirrhosis defines a risk with decreased survival. Eur J Gastroenterol Hepatol 2016;28:1285-1292.

16. Bruns T, Sachse S, Straube E, et al. Identification of bacterial DNA in neutrocytic and non-neutrocytic cirrhotic ascites by means of a multiplex polymerase chain reaction. Liver Int 2009;29:1206-1214.

17. Bruns T, Reuken PA, Stengel S, et al. The prognostic significance of bacterial DNA in patients with decompensated cirrhosis and suspected infection. Liver Int 2016;36:1133-1142.

18. Appenrodt B, Lehmann LE, Thyssen L, et al. Is detection of bacterial DNA in ascitic fluid of clinical relevance? Eur J Gastroenterol Hepatol 2010;22:1487-1494.

19. Angeli P, Bernardi M, Villanueva C, et al; European Association for the Study of the Liver. EASL Clinical Practice Guidelines for the management of patients with decompensated cirrhosis. J Hepatol 2018;69:406-460.

20. Friedman ND, Kaye KS, Stout JE, et al. Health care-associated bloodstream infections in adults: a reason to change the accepted definition of community-acquired infections. Ann Intern Med 2002;137:791-797. 
21. Alexopoulou A, Papadopoulos N, Eliopoulos DG, et al. Increasing frequency of gram-positive cocci and gram-negative multidrugresistant bacteria in spontaneous bacterial peritonitis. Liver Int 2013;33:975-981.

22. Alexopoulou A, Vasilieva L, Agiasotelli D, et al. Extensively drug-resistant bacteria are an independent predictive factor of mortality in 130 patients with spontaneous bacterial peritonitis or spontaneous bacteremia. World J Gastroenterol 2016;22:4049-4056.

23. Moreau R, Jalan R, Gines P, et al; CANONIC Study Investigators of the EASL-CLIF Consortium. Acute-on-chronic liver failure is a distinct syndrome that develops in patients with acute decompensation of cirrhosis. Gastroenterology 2013;144:1426-1437, 1437.e1-e9.

24. Clinical and Laboratory Standards Institute (CLSI). Performance Standards for Antimicrobial Susceptibility Testing, M100, $30^{\text {th }}$ edition. Available from: https:/clsi.org/standards/products/ microbiology/documents/m100/[Accessed 3 July 2021].

25. Magiorakos AP, Srinivasan A, Carey RB, et al. Multidrug-resistant, extensively drug-resistant and pandrug-resistant bacteria: an international expert proposal for interim standard definitions for acquired resistance. Clin Microbiol Infect 2012;18:268-281.

26. Chang SS, Hsieh WH, Liu TS, et al. Multiplex PCR system for rapid detection of pathogens in patients with presumed sepsis - a systemic review and meta-analysis. PLoS One 2013;8:e62323.

27. Opota O, Jaton K, Greub G. Microbial diagnosis of bloodstream infection: towards molecular diagnosis directly from blood. Clin Microbiol Infect 2015;21:323-331.

28. Pelletier G, Salmon D, Ink O, et al. Culture-negative neutrocytic ascites: a less severe variant of spontaneous bacterial peritonitis. J Hepatol 1990;10:327-331.

29. Kamani L, Mumtaz K, Ahmed US, Ali AW, Jafri W. Outcomes in culture positive and culture negative ascitic fluid infection in patients with viral cirrhosis: cohort study. BMC Gastroenterol 2008;8:59.

30. Francés R, Benlloch S, Zapater P, et al. A sequential study of serum bacterial DNA in patients with advanced cirrhosis and ascites. Hepatology 2004;39:484-491. 